\title{
IMPLEMENTING EUROPEAN STANDARDS IN THE ESP CURRICULUM FOR STUDENTS OF NON-LINGUISTIC SPECIALITIES IN UKRAINIAN UNIVERSITIES
}

\author{
Nadia Grytsyk \\ Chernihiv, Chernihiv National Pedagogical University named after T. G. Shevchenko \\ nadiela@yandex.ru
}

\begin{abstract}
The article presents the current tendencies in teaching English for Specific Purposes (ESP) for students of nonlinguistic specialities in the European context. The author analyses the requirements of English language proficiency set by the Common European Framework of Reference for Languages (CEFR), in the context of European integration processes. The National ESP Curriculum for Universities (2005) focuses on the necessity to acquire professional and functional communicative competence in English by the graduates, providing an opportunity for effective functioning in a professional environment. The current challenges in the ESP field in Ukraine are caused by the integration of the Ukrainian education system into the international academic community. The present situation of ESP teaching, learning and assessment does not satisfy the needs of students of non-linguistic specialities in Ukrainian higher educational institutions. The author discusses the idea of incorporating international English tests, such as FCE, CAE, IELTS and TOEFL in a higher education environment in Ukraine as a part of teaching ESP. The possibility of gaining the international experience in the field of certification and evaluation of students' English language proficiency level in accordance with the European requirements and criteria will help future specialists to develop their professional foreign language competence. The improvement and development of new forms and methods of ESP training and assessment in accordance with CEFR will give an opportunity for students to succeed in the competitive job market in the future.

Keywords: foreign language education; English for Specific Purpose; International English Tests; Common European Framework of Reference for Languages; assessment; certification.
\end{abstract}

Introduction. Globalization of the world economy requires professionals in various areas to communicate effectively in foreign languages. The success in intercultural professional communication depends on the ability to deal with language and cultural barriers, i.e. on the language skills and competences regarding a professional area. So that is why the problem of foreign language education is very important at the present stage for Ukraine, because in the context of globalization and European integration the system of higher education is aimed at training highly qualified experts who are able to meet the challenges of today's global working world.

It is commonly accepted that the key and necessary competence of a modern specialist is the obligatory knowledge of at least one foreign language. This, in particular, is stated in the government strategic documents the National Doctrine of Education Development (The Decree of the President of Ukraine, 344, dated 25 June 2013, and the Decree of the President of Ukraine, 642, dated 9 July 2009), the National Education Development Strategy for the period 2012-2021, by the decrees of the President of Ukraine "On additional measures of the education development in Ukraine", "Main directions of higher education reform", etc.

Under the influence of changes in society in recent years the English language has been acknowledged as one of the most widely spoken languages and is considered to be the most accepted form of communication in the business world. It is the official language of the European Union and is studied as the second language in most of the countries across the world (Crystal, 1997, p.8). Today, knowledge of the English language has become the basic requirement in most of the professions and industries. The researchers note that English is dominated in different social sectors, such as commerce, finance, scientific research in higher education, the media, pop culture (May \& Homberger, 2008). It is worth saying that without knowledge of a foreign language (especially, English) it is hardly possible nowadays to apply for a senior position and get a prestigious well-paid job.

In such a situation the main task of higher educational institutions is to help future specialists to develop professional foreign language competence. This demand has generated the establishment of a new linguistic branch - the English for Specific Purposes (ESP). The problem of improving 
professioally oriented foreign language acquisition has been studied in the works of S. Burger, M. Wesche, M. Migneron, N. Cloud, O. Tarnopolskyi, S. Kozhushko, Z. Korneva, etc.

The purpose of this article is to analyse the process of ESP establishment in Ukraine in the European context by paying attention to the current problems in teaching ESP at non-linguistic universities, to discuss the possible solutions and give recommendations.

English for Specific Purposes (ESP). While discussing the major aspects of ESP development in Ukraine it is necessary to distinguish that the formation of ESP as a significant field of English Language Teaching (ELT) has a long history. It was introduced in the 1960-ies, when it became clear that General English courses frequently did not meet the requirements of students or workers and their specific fields of work (May \& Homberger, 2008). The founders of ESP were Tom Hutchinson and Alan Waters (Hutchinson, 1987, p.18). ESP courses are designed to meet the specified needs of a particular group of prospective professionals. The course material of ESP is designed by taking specific jargon and terminology concerned with the specific fields that concentrate on the use of English in those respective contexts. The importance of the professional context of foreign language education contributed to the creation of professionally oriented teaching foreign languages in a separate educational area (Bracaj, 2014), which was called "vocationally oriented language learning" at the intergovernmental Symposium on learning languages in multicultural Europe project of the Council of Europe "Modern languages. Language learning for European citizenship" (1989-1996) in November 1989 in Sintra, Portugal.

Common European Framework of Reference for Languages (CEFR). The development of the vocationally oriented language learning led to the introduction of the CEFR and its implementation in the educational system. The main goal of the CEFR system is to provide the method for evaluation and learning applicable to all European languages. In November 2001, the EU resolution recommended using CEFR to create national systems of assessment of linguistic competence (CEFR, 2003, p.4). In accordance with the CEFR, there are six levels of language proficiency developed by the Association of Language Experts ALTE (The Association of Language Testers in Europe): basic user (Breakthrough or A1; Waystage or A2), independent user (Threshold or B1; Vantage or B2), proficient user (Effective Operational Proficiency or C1; Mastery or C2) (CEFR, 2003). They have measures from basic to perfect level of English knowledge, according to which the graduates of higher non-linguistic educational institutions should have professionally oriented foreign language skills in all types of language competence, the level of formation is determined by the basis of educational and qualification characteristics of a specialist. All dictionaries, handbooks, tests and study guides of any European language are oriented on CEFR.

National ESP Curriculum for Universities. When Ukraine has declared its intention to become an equal partner in the context of the Bologna process, it is expected that the Ukrainian schools will carry out educational process in accordance with European standards of language proficiency (National ESP Curriculum, 2005).

With the purpose of systematization of language learning by citizens, especially the youth of Ukraine, the government accepted the Recommendation N. R (98) 6 of the Committee of Ministers of the Council of Europe "Modern Languages". According to the Appendix of the Recommendation N. R (98), a suggestion was made to promote and widespread multilingualism. And with this purpose the Committee of Ministers proclaimed to 1) involve English learning at all levels of the curriculum, using a flexible approach, including module courses and, therefore, recognizing them in the national qualifications system (e.g. public examinations); 2) encourage using foreign languages in teaching non-linguistic subjects (e.g. history, geography, mathematics) and creating favourable conditions for teaching process.

Due to the above-mentioned reasons a team of Ukrainian professionals with the approval of the Ministry of Education and Science of Ukraine under the guidance and with the help of the British Council Ukraine established the National ESP Curriculum for Universities in 2005 (National ESP Curriculum, 2005). Such developments were done as a response to international developments for individual language needs of university students; in order to provide benchmarks for teachers and students in line with the levels identified in CEFR; to establish a standardized basis for course design by teachers of English for different specialities. 
The aim of the programme is to develop students' professional language skills that will influence their effective functioning in the cultural diversity of educational and professional environments. The academic discipline "English for Specific Purpose" for non-linguistic higher educational establishments is one of the branches of vocational training, which ensures the formation of students' adaptation to professional activity.

A recommended Mode of the National ESP Curriculum for Universities suggests forming and developing the professional communicative competence of students of higher educational institutions, which is described as a verbal behaviour that is specific to the academic and professional environment. It means that each student is required to obtain linguistic competence (speech and language skills), socio-cultural and professional communication on the level B2 ("independent user"). So, in accordance with the National ESP Curriculum for Universities (National ESP Curriculum, 2005, p.38) students of non-linguistic specialities will be able to:

- understand how core values, beliefs and behaviour in Ukrainian academic or professional environment differ from culture to culture (international, national, institutional);

- understand different corporate cultures within specific professional contexts and how they relate to each other;

- apply intercultural insights while interacting orally or in writing to immediate academic and professional situations;

- behave and react appropriately in common social, academic and professional situations in everyday life, and know the rules of how people should interact in these situations (recognize appropriate gestures, eye contact, personal space, and body language in each situation.

The mentioned above requirements can be easily explained by the fact that the process of foreign language training for non-linguistic specialities is substantially different from teaching a foreign language as the main subject. In this case, the process of foreign language education as a language of professional communication combines the knowledge of foreign language and speciality.

The main objective of teaching a foreign language in non-linguistic higher educational institutions is to develop professionally oriented communicative competence. The National ESP Curriculum for Universities was designed to specify the overall aim of ESP teaching and learning (National ESP Curriculum, 2005, p.30), with the task to prepare students to communicate effectively in English in their everyday professional activity. According to the National ESP Curriculum for Universities, which is based on the CERF (National ESP Curriculum, 2005), it is stated that to qualify for a Bachelor`s degree, together with other professional skills, future specialists should be able to:

- prepare public presentations on a large number of professional issues, using appropriate means of verbal communication and adequate forms of reference for discussions and debates;

- find the new text, graphic, audio and video information in English (both printed and in electronic form), using appropriate search methods and terminology;

- analyse English language information sources to obtain data necessary to perform professional tasks and taking professional decisions;

- write professional texts and documents in English for a number of professional issues;

- write business and professional letters, demonstrating intercultural understanding and knowledge in a specific professional context;

- translate professional English texts into the native language, using bilingual terminological dictionaries, electronic dictionaries and translation software directions.

Developing professional foreign language competence on an appropriate level requires a definite amount of classroom hours. According to the CEFR, by the end of the ESP course, each student of non-linguistic specialty has to achieve the level B2 of language proficiency. For mastering the educational qualification of "Bachelor" 270 classroom hours or 7.5 ECTS credits are needed (1 ECTS credit $=36$ hours) without individual work; to reach the $\mathrm{B} 2+, \mathrm{C} 1$ level of language proficiency for the educational qualification of "master", students are provided with 200-250 academic hours.

In Ukrainian higher educational institutions the situation with the distribution of classroom hours for mastering ESP by students of non-linguistic specialities is different. The number of academic hours is regulated by the decree of the Ministry of Education and Science of 
Ukraine № 642, dated the 9th July 2009 "About the Organization of Studying the Humanities". According to this document, students are provided with 5 ECTS credits (equivalent to 180 hours of teaching load with the individual work) for studying ESP. It is necessary to point out that usually the ESP course that introduces students to their profession is taught during the $1^{\text {st }}$ and $2^{\text {nd }}$ year of studying. In fact, the restricted amount of English classes at non-linguistic universities only complicates the necessity in teaching professionally oriented English in order to develop all the necessary English communication skills and competences as well as to reach the target level B2.

International English Tests. It is quite obvious, that students' knowledge of English in Ukraine cannot satisfy the requirements of certification language skills, set by the CEFR, in the context of the country's integration into the world educational community.

It is worth saying, that today the entry in the curriculum vitae about the knowledge of English, such as FCE, CAE, BEC (Cambridge ESOL, 2011) can give the employer much more information than subjective "I can speak English" or "I speak English fluently". "Fluently" is often in practice means "I can start a conversation", but professionals are required to be able to negotiate, give presentations and engage in business correspondence in English.

Table 1 presents the list of international exams in English in accordance with the European system (Cambridge ESOL, 2011). So, to pass most of the exams in ESP at least the level B1 is required (academic English - IELTS and English for business - BEC); "legal" and "financial" English (ILEC and ICFE respectively) start with the level B2. With the exception of the exams, BULATS (Business Language Testing Service) covers all six levels, from A1 to C2.

Table 1

International English Tests

\begin{tabular}{|c|c|c|c|c|c|c|}
\hline $\begin{array}{l}\text { European } \\
\text { System of levels }\end{array}$ & General English & \multicolumn{4}{|c|}{ Academic English } & $\begin{array}{l}\text { Professional } \\
\text { English }\end{array}$ \\
\hline $\mathrm{C} 2$ & $\mathrm{CPE}$ & \multirow{4}{*}{$\begin{array}{l}\text { I } \\
\text { E } \\
\text { L } \\
\text { T } \\
\text { S }\end{array}$} & & & & BULATS \\
\hline $\mathrm{C} 1$ & CAE & & BEC higher & \multirow[t]{2}{*}{ ILEC } & \multirow[t]{2}{*}{ ICFE } & \\
\hline $\mathrm{B} 2$ & FCE & & BEC (vantage) & & & \\
\hline $\mathrm{B} 1$ & PET & & BEC preliminary & & & \\
\hline $\mathrm{A} 2$ & YLE (flyers) / KET & & & & & \\
\hline A1 & YLE movers & & & & & \\
\hline & YLE starters & & & & & \\
\hline
\end{tabular}

The given examples demonstrate that the incorporation of International English Tests in the contents of ESP programs for students of non-linguistic specialties will improve the system for monitoring the level of formation of communicative competence of future specialists in various professional fields (Tarnopolsky\& Korneva, 2013, p.217).

Results and recommendations. As a result of integration the European standards in the field of ESP teaching in higher educational institutions in Ukraine, we found out that there are still a lot of difficulties. We offer some recommendations to improve the process of ESP teaching for students of non-linguistic specialities. They are the following:

1. Every Bachelor's graduate should have the same amount of English classes devoted to studying professionally oriented English in order to develop all the necessary English communication skills and competences as well as to reach the target level B2;

2. International English Tests should be added to incorporate the contents of ESP programs;

3. More attention should be paid to the improvement of the methodological and organizational basis of ESP teaching, the content of the course, the specification of the existing programs, the development of textbooks and teaching materials for each specialty;

4. Improvement of forms and methods of evaluation and certification of results in accordance with the CEFR should be made.

Conclusions. Summarizing the information collected, it can be concluded that the current challenges in the field of ESP teaching, learning and assessment in Ukraine are caused by the integration of the Ukrainian education system into the international academic community. The implementation of International English Tests into the process of teaching ESP in Ukrainian higher 
educational institutions in accordance with CEFR, set by the Council of Europe will undoubtedly lead to positive changes and transformations of the foreign language education. Putting into practice the international certification of English proficiency is possible under the support of the Ukrainian university authorities as well as through the implementation of educational reforms and public funding.

\section{References:}

Cambridge ESOL. Principles of Good Practice - Quality management and validation in language assessment (2011). Cambridge: Cambridge. ESOL. Available online at http://www.cambridgeenglish.org/images/126011-using-cefrprinciples-of-good-practice.pdf

Cloud, N. (2009). Literacy Instruction for English Language Learners. Portsmouth, Heinemann.

Common European Framework of Reference for Languages: Learning, teaching, assessment. (2003). Cambridge: Cambridge University Press.

Crystal, D. (1997.) English as a Global Language. Cambridge: Cambridge University Press. http://dx.doi.org/10.1017/CBO9780511486999

English for Specific Purposes (ESP) National Curriculum for Universities. (2005). Ministry of Education and Science of Ukraine. British Council Ukraine. Kyiv, Ukraine: Lenvit.

Hutchinson, T. \& Waters, A. (1987). English for specific purposes: A learner-centred approach. Cambridge: Cambridge University Press. http://dx.doi.org/10.1017/cbo9780511733031

Morena, B. (2014).Teaching English for Specific Purposes and Teacher Training. European Scientific Journal, 10(2).

Recommendation № R (98) 6 of the Committee of Ministers to member states concerning modern languages. Council of Europe. Committee of Ministers. http://dx.doi.org/10.1017/S0261444800013379

May, S. \& Homberger, N. (2008). Encyclopedia of Language and Education.Vol. 1. Springer Science+Business Media, LLC.

Kornieva, Z.M. (2011). The Conceptual bases of the textbook creation in experiencing methodology of teaching foreign languages. The Journal of Dnipropetrovsk University of Economy and Law named after Alfred Nobel. "Pedagogy and Phsycology", 1,76-83.

Standards Ukraine. (2013). The National Education Development Strategy in Ukraine for the period up to 2021. [The Decree of the President of Ukraine, 344, dated by 25 June 2013]. Retrieved June 25, 2013 from http://www.president.gov.ua/documents/15828.html

Standards Ukraine. (2009). Pro orhanizatsiiu vyvchennia humanitarnykh dystsyplin za vilnym vyborom studenta. Nakaz MON Ukrainy №642 vid 09.07.2009r.[The Document of Minister of Education and Science of Ukraine "About the Organization of Studying Humanities by the freechoice". The Decree of the President of Ukraine, 642, dated 9 July 2009]. Retrieved July 9, 2009 from http://mon/gov/ua/ua/about-minisry/normative/147

Tarnopolskyi, O.B. (2008). Metodyka navchannia studentiv vyshchykh navchalnykh zakladiv pysma anhliiskoiu movoiu: posibnyk dlia studentiv vyshchykh navchalnykh zakladiv [The Methodology of Teaching Writing in English of Students in Higher Educational Institutions]. Vinnytsia, Ukraine: Nova knyha.

Tarnopolskyi, O. \& Kornieva, Z.(2013). Integracija obuchenija jazyku i special'nosti v nejazykovom vuze [The Integration of Teaching Language and Speciality in Non-linguistic Higher Educational Institution.]. Saarbrucken, Germany: LAP LAMBERT, Academic Publishing. 